\title{
EFFICACY OF SINGLE DOSE ANTICOAGULANTS AGAINST RODENTS DAMAGING COCONUT
}

\section{S. SADAKATHULLA ${ }^{1}$ and A. ABDUL KAREEM ${ }^{2}$}

\section{Professor (Entomology), Coconut Research Station, Veppankulam - 614 906, S. India.}

2. Director, Tamil Nadu Rice Research Institute, Aduthurai - 612 101, S. India.

\section{ABSTRACT}

Crown baiting with bromodiolone 0.005 per cent ready made rodenticide cake @ four bits, weighing $16.5 \mathrm{~g}$ each at the base of the four bunches bearing the tender nuts of fist size and above on four sides in the crown of palm was found very effective in controlling rodent damage.

\section{INTRODUCTION}

Coconut palm is attacked by a number of insect and non insect pests, of which rodents are considered more serious among the non insects. The rodents attack the standing crops almost at every stage in the field. Rodents are important pests of coconut in almost all the 76 coconut growing countries in the world. Coconut being a perennial crop, provides a regular and abundant food and water supply to rodents throughout the year. Its crown provides an ideal environment, facilitating rodents to reproduce profusely and maintain a higher level of population (Advani, 1985). The common black rat, Rattus rattus wroughtoni Hinton, the house rat, Rattus rattus rufuscens Gray and the south Indian. Squirrel, Funambulus palmarum Linn are common ones responsible for the heavy nut shedding due to their attack in Tamil Nadu.

Three to six months old tender nuts were preferred by the rodents. The damage to buttons, tender nuts and in severe inflestations, the damage to leaf stalks, unopened spathes, female flowers, male flowers were recorded (Bhat and Sujatha, 1989 a). The crop loss for coconut to be 5.7 to 16 per cent in some parts in India, while it was 21 to 28 per cent in Kerala (Srivastava, 1975; Bhat and Sujatha, 1989 a). As high as 77 per cent damage on tender nuts was noticed in Gilbert and Ellice islands (Smith 1970). The rodent damage was very high in poorly managed and closely planted gardens (Singh, 1976; Krishnamoorthy, 1983). Hence an in vivo experiment was laid out at Coconut Research Station, Tamil Nadu Agricultural University, Veppankulam, during 1991 '92, with single dose rodenticides to evolve an effective chemical control method for rodents.

\section{MATERIALS AND METHODS}

A field experiment was laid out in randomised block design, replicated ten times with three treatments viz., (1) bromadiolone 0.005 per cent ready - to - use cake 4 bits of $16.5 \mathrm{~g}$ each per palm (2) rodacake 0.025 per cent ready - to - use cake @ 4 bits of $15.0 \mathrm{~g}$ each per palm and (3) a control.

The ready - to - use rodenticide cake bits were placed on the upper base of the bunches bearing the tender nuts in the palm crown. Four cake bits were placed likewise on four such bunches on four directions carefully at one each per base of the tender nut bunch, so that the cakes did not fall 
from the palm crown. Before and after this process of application, the observation on the rodent damage were followed and the relative efficacy of the ready - to - use rodenticides was evaluated.

\section{RESULTS AND DISCUSSION}

Application of bromadiolone 0.005 per cent ready made rodenticide cake @ four bits each weighing $16.5 \mathrm{~g}$ per palm kept in the palm crown significantly controlled rodent damage in tender nuts of fist size and above (Table 1). The success with poison bait mostly depends upon many considerations such as attractivity, palatability toxicity, stability, physical condition, time, place and mode of exposure. Otherwise it leads to "bait-shyness" on rats (Prakash and Ojha, 1978 and Cowan et al 1979) and on squirrels (Bhat, 1979). The results of the present study were in confirmity with the findings of Jain (1986), Subiah and Misra (1980), Jhala et al (1984) and Bhat and Sujatha (1989 b). Pre-baiting is the solution to check the bait shyness among rodents (Jain, 1985, 1986). Once in $\mathbf{4 5}$ days, the palm growers allow their workers to climb the palm for the harvest. Prebaiting has to be done at least 2 to 3 times. Hence most of the growers do not follow pre-baiting as it involves more expenditure on labour to climb the palms. As pre-baiting involves more expenditure on labour, the effective ready made rodenticide bromodiolone 0.005 per cent cake can be effectively utilised for controlling the ordents damaging tender nuts, as it does not require prebaiting.

In the present study, a single applicantion of bromadiolone 0.005 per cent ready made rodenticide cakes to the palm crown was found to be more effective than the 'two times' application of the above rodenticide cake at intervals of 12 days, as suggested by Bhat et al (1991).

Table 1: Efficacy of single dose ready made rodenticides in the control of rodent damage in palms*

\begin{tabular}{cc}
\hline Treatments & $\begin{array}{c}\text { Mean per cent reduction } \\
\text { of rodent damage }\end{array}$ \\
\hline
\end{tabular}

Bromadiolone 0.005 per cent

Rodacake 0.025 per cent

Untreated check

$\mathrm{CD}(\mathrm{P}=0.05)$

2.16

* Mean of ten replications

(Figures in parentheses are arcsine transformed values)

\section{CONCLUSION}

Crown baiting of bromadiolone 0.005 per cent ready make rodenticide cake @ four bits per palm at the upper base of the four bunches bearing the tender nuts of fist size and above on four sides in the coconut palm crown was found very effective in controlling rodent damage. As this technique does not require pre-baiting it will be economical too. 


\section{REFERENCES}

Advani, R. (1985) Rodent pest management in the coconut plantations of India and its Islands. Indian Coconut J. 15 (10): 3 - 9.

Bhat, S. K. (1979) Studies on the bait preference of the western Ghats squirrel, Funambulus tristriatus W. in captivity : 1 - grains. Indian J. Rodent. 1 (I \& 2): 10 - 16.

Bhat, S. K. and A. Sujatha. (1989 a) Prevent rat damage to tender coconut by bromadiolone baits. Indian Coconut J. 20 (7): 3 - 6.

Bhat, S. K. and A. Sujatha. (1989 b) Relative acceptance of different baits by Rattus rattus wroughtoni Hinton. J. Plant. Crops 17 (2): 123 - 126.

Bhat, S. K., P. S. P. V. Vidyasagar and A. Sujatha (1991) Studies on the biology and control of Rattus rattus wroughtoni Hindon, a pest of coconut in India. Proc. International Symp. on Coconut Res. \& Devept. II. Kasaragod, Kerala (Abstr.). P. 10.

Cowan, P. E., K. Srihara and S. Srihara, (1979) Preliminary study on bait shyness in Bandicota bengalensis towards zinc phosphide. Curr. Sci. $48: 85$ - 86 .

Jain, A. P. (1985) Pre-baiting to check bait-shyness among rodents. Indian Farnt. 35 (3) : 25.

Jain, A.P. (1985) A simplified rodent baiting technique. Indian Farm. 36 (8) : 33 - 34.

Jhala, R. C., A. H. Shah, R. C. Patel and R. L. Patel. (1984) Effectiveness of bromadiolone and warfarin wax cakes against rats damaging coconut palms in South Gujarat.

Rodent Newsl. 8 : 5-6.

Krishnamoorthy, B. (1983) Rodent problem in Lakshadweep. Indian Coconut J. 8 (11) : 3 - 4.

Prakash, I. and P. Ojha. (1978) The phenomenon of poison bait aversion and its possible attenuation in the Indian gerbil, Tatera indica indica (Hardwicke). Z. angew Zool. $65: 385-395$.

Singh, G. (1976) Rodent problem. In : Ann. Report Central Plantation Crops Research Instt., Kasaragod. pp. 206 - 207.

Smith, F. J. (1970) Research on rats on the atolls. Olegineux $25: 147-152$.

Srivastava, A. S. (1975) Rodent eradication : A break through in protection technology. Proc. of All India Rodent Control Sem. Ahmadabad. pp. 42 \& 46.

Subiah, K. S. and P. Misra. (1980) A first field report of bromadiolone in India. Rodents Newsl. 4 (2): $13-14$. 